\title{
Evaluation of Green Clover Leaves as Green and Economic Sorbent for Removal of High Levels of Iron from Different Water Sources
}

\author{
${ }^{*} H_{a s s o u n a}{ }^{1}$ MEM, Elbably ${ }^{2}$ MA, Marzouk ${ }^{3}$ MA and El Maghrabi ${ }^{1}$ AH \\ ${ }^{1}$ Department of Chemistry, Faculty of science, Beni-Suef University, Egypt \\ ${ }^{2}$ Department of Hygiene, Management \& Zoonoses, Faculty of Veterinary Medicine, Beni-Suef University, Egypt \\ ${ }^{3}$ Department of Botany \& Microbiology, Faculty of science, Beni-Suef University, Egypt
}

Submission: December 12, 2016; Published: January 05, 2017

*Corresponding author: : Hassouna MEM, Department of Chemistry, Faculty of Science, Beni-Suef University, Beni-Suef 62514, Egypt

Abstract

Green clover powdered leaves and their modified forms with lactic acid and tri sodium citrate have been used as low cost and eco-friendly adsorbents for the removal of iron from aqueous media. Samples were collected from different water supplies (surface, tap and ground water). The different factors affecting the adsorption procedure such as: adsorbent dose, stirring time and $\mathrm{pH}$ have been optimized for the sake of realizing maximum removal efficiency. The removal efficiency of the unmodified green clover was increased with the increase of the $\mathrm{pH}$ value until reaching its maximum uptake in the range 4-7. Both the sodium citrate and lactic acid modified green clover powders showed maximum uptake in the $\mathrm{pH}$ range 5-6. The removal process was slow in the first $35 \mathrm{~min}$. then the uptake\% was gradually increased till equilibrium after $50 \mathrm{~min}$ in case of unmodified green clover, the tri sodium citrate modified form showed equilibrium after $40 \mathrm{~min}$. and the lactic acid modified one reached equilibrium after $50 \mathrm{~min}$. Desorption processes proved the possibility of regeneration and reuse of the adsorbent.

Modified forms displayed better adsorption capacity and capability comparable with that of the crude leaves. The removal process was applied on some samples of wastewater successfully.

Keywords: Water sources; Heavy metals; Fe; Green clover leaves; Economic sorbent; Adsorption

\section{Introduction}

Air, food, soil and water were narrated to be the media where heavy metals such as copper, cadmium, nickel, lead, and zinc are introduced into the environment [1-4]. Heavy metals cause serious health disease, including reduced growth and development, cancer, organ and nervous system damage. In severe cases, it leads to death [5]. These heavy metals are reported to be hazardous resulting in damage to ecosystems as well as human health $[6,7]$ especially if their concentration is more than the accepted limit [8]. Their higher sources include contaminant water discharged from hospitals [9], several industries such as $\mathrm{Cd}-\mathrm{Ni}$ battery, metal plating and alloy manufacturing [10-13]. Chemical precipitation, ion exchange, electrodialysis, solvent extraction, coagulation, evaporation and adsorption are among the most known techniques for the removal of metal ions from aqueous solutions [14-17].

Iron is one of the earth's most spreading resources making up about $5 \%$ of the earth crust. It is one of the major heavy metal impurities that are commonly present in many water sources which cause several problems for the human health [18]. There are many methods for removal of iron from ground water, viz., oxidation with chlorine and potassium permanganate, treatment with limestone, liquid-liquid extraction, ion exchange, chemical precipitation, bioremediation, activated carbon and other filtering materials [19-23]. Many of these methods became not economically feasible for the removal processes.

In recent years, the need for safe and economical methods has necessitated the use of low cost agricultural by-products such as sugarcane bagasse [24-26], rice husk [27,28], sawdust $[29,30]$, coconut husk [31], oil palm shell [32], black gram husk [33], neem bark [34] , tea waste, turkish coffee and walnut shell. Some more adsorbents like papaya wood [35], maize leaf [36], teak leaf powder [37], coraindrumsativum [38], lalang (Imperata cylindrica) leaf powder [39], peanut hull pellets [40], sago waste [41], saltbush (Atriplex canescens) leaves [42,43], tree fern [44-45], grape stalk wastes [46], etc. Sorption methods are 
considered flexible and easy to operate with much less sludge disposal problems and economically feasible $[47,48]$.

However, the expense of individual sorbents varies depending on the degree of processing required and local availability. In general, an adsorbent can be termed a low cost one if it requires little processing, abundant in nature, an agricultural waste or is a by-product or a waste material from an industry. On the other hand, plant wastes can be used in their crude form, or in most cases, require to be modified or treated for being applied for the cleansing of heavy metals. Thus, the present study was forwarded towards the use of green clover powdered leaves as economic sorbent in both crude and modified forms with tri sodium citrate and lactic acid for removal of iron from different water sources. The different factors affecting the adsorption procedure such as: adsorbent dose, stirring time and $\mathrm{pH}$ have been optimized to achieve maximum removal efficiency.

\section{Experimental}

\section{Materials and Methods}

\section{a) Chemicals}

Ferrous ammonium sulphate (Aldrich), Hydrochloric acid (BDH), 1, 10 Phenanthroline(Aldrich) Tri sodium citrate (Aldrich) and Hydroxylamine hydrochloride(Aldrich).

\section{b) Reagents}

i. Standard Iron (II) solution

(1000 ppm) Fe (II) stock solution was prepared by dissolving $0.7016 \mathrm{~g}$ of ammonium ferrous sulphate $\left(\mathrm{NH}_{4}\right)_{2} \mathrm{SO}_{4}$. $\mathrm{FeSO}_{4} \cdot 6 \mathrm{H}_{2} \mathrm{O}$, (Aldrich, USA) in DDW containing $5 \mathrm{~mL}$ conc. $\mathrm{H}_{2} \mathrm{SO}_{4}$ and accurately diluted with water to volume in 100 $\mathrm{mL}$ volumetric flask.

\section{ii. 1,10 Phenanthroline $(0.2 \%)$}

Phenanthroline hydrochloride or hydrate (phen), in $100 \mathrm{~mL}$ vol. flask 0.2 gm of phenanthroline were

dissolved in doubly distilled water (DDW) and diluted to the mark with in $0.1 \mathrm{M} \mathrm{HCl}$.

iii. Tri sodium citrate $(10 \%)$ solution

in $100 \mathrm{~mL}$ vol. flask, $10 \mathrm{~g}$ of tri sodium citrate were dissolved in doubly distilled water (DDW) and diluted to the mark.

iv. Hydroxylamine hydrochloride (10\%)

$10 \mathrm{~g}$ of hydroxylamine- $\mathrm{HCl}$ were dissolved in DDW and diluted to $100 \mathrm{~mL}$.

c) Preparation of the green leaves clover powder and its modified forms:

\section{i. Preparation of the green clover leaves powder}

Green clover leaves are collected from the agricultural Egyptian fields. The leaves are washed, air dried and then are finely powdered in a mixer till being near the nano size. The final product is applied as the crude green clover leaves powder for the removal of iron from water samples according to the proposed procedure.

\section{ii. Lactic Acid Modified Green Clover leaves powder}

$100 \mathrm{~g}$ of the crude green clover powder are refluxed with $500 \mathrm{ml}$ of $0.5 \mathrm{M}$ lactic acid solution over a boiling water for 6 h.The produced precipitate was separated, repeatedly washed with DDW till free from acid then dried in an oven at $60^{\circ} \mathrm{C}$ for two hrs. After cooling in a desiccator to room temperature, it is finely grinded once again.

\section{iii. Tri Sodium Citrate Modified Green Clover leaves powder:}

$100 \mathrm{~g}$ of the crude green clover powder are, similarly, refluxed with $500 \mathrm{~mL}$ of $0.5 \mathrm{M}$ trisodium citrate solution over a boiling water bath for $6 \mathrm{~h}$. The produced precipitate was separated, repeatedly washed with DDW till free from both the sodium and citrate ions, then dried and grinded.

\section{Instruments}

UV/Vis. Spectrophotometer (Shimadzu UV/Vis. Perkin Elemer Lambada 3B Spectrophotometer using 1cm Quartz cell" was used for the determination of residual iron in the effluents after the adsorption processes); Flame Atomic Absorption Spectrophotometer AA 240FS, Agilent Technologies, used for rapid and confirmational determination of iron; $\mathrm{pH}$ meter (The $\mathrm{pH}$ measurements were carried out using the microprocessor pH meter BT 500 BOECO, Germany, which was calibrated against two standard buffer solutions at pH4 and 9 and Mechanical Shaker (with up to $200 \mathrm{rpm}$ with speed control was used).

The morphologies of the prepared samples and composites were investigated using Scanning Electron Microscopy (SEM), $\mathrm{X}$-Ray diffractometer was used to investigate the phase structure of the investigated samples under the following conditions which were kept constant in all the analysis processes $\mathrm{Cu}$ : X-ray tube, scan speed $=8 / \mathrm{min}$, current $=30 \mathrm{~mA}$, voltage $=40 \mathrm{kV}$ and preset time $=10 \mathrm{~s}$.

\section{Procedure}

\section{Spectrophotometric Method for Determination of iron}

The residual iron in the solution is determined spectrophotometrically after its reduction to Fe (II). In a $25 \mathrm{~mL}$ volumetric flask, add $0.5 \mathrm{~mL}$ of the $10 \%$ hydroxylamine solution, $2 \mathrm{~mL} 10 \%$ tri sodium citrate solution then transfer $5 \mathrm{~mL}$ of the standard Fe (II) solution. The $\mathrm{pH}$ is in the range 3-4. Add $2.5 \mathrm{~mL}$ of $0.2 \% 1,10$ phenanthroline solution, dilute to the mark with DDW and mix thoroughly. After 5 min the absorbance of the solution is measured at $512 \mathrm{~nm}$ against a blank.

\section{Flame Atomic Absorption procedure}

The concentration of residual iron in the solution after the adsorption process is directly measured at $\lambda_{\text {max }}$ equals $372.0 \mathrm{~nm}$ with detection limit of $50 \mu \mathrm{g} / \mathrm{L}$ using a mixture of Acetelyne Nitrous Oxide flame. 
Optimization of the factors affecting the extraction of iron from standard solutions

\section{i. Optimization of the $\mathrm{pH}$}

To investigate the effect of $\mathrm{pH}$ on the uptake \% (adsorption) of iron from aqueous media by the crude green clover leaves powder, aliquots of $25 \mathrm{~mL}$ containing $20 \mathrm{ppm}$ of the metal ion are transferred to a group of $100 \mathrm{~mL}$ conical flasks each containing $0.1 \mathrm{~g}$ of the crude adsorbent. Adjust the $\mathrm{pH}$ of each flask to a value ranging from $2-10$, respectively using $0.1 \mathrm{M} \mathrm{NaOH}$ and $\mathrm{HCl}$ solutions and stir for $1 \mathrm{hr}$. Centrifuge the contents of each flask and determine the residual iron content in the supernatant solution. The sorption percentage of the metal ion by the green clover leaves powder is calculated from the relation:

$$
\text { Uptake }(\%)=\left[\left(\mathrm{C}_{0}-\mathrm{C}\right) / \mathrm{C}_{0}\right] \times 100
$$

Where $\mathrm{C}_{\mathrm{o}}$ and $\mathrm{C}$ are the initial and final concentrations of metal ion respectively. The optimum $\mathrm{pH}$ was found to be in the range 4-7.

When the same procedure was parallely repeated using the sodium citrate and lactic acid modified powder instead, the optimum $\mathrm{pH}$ was in the range 5-6.

\section{ii. Sorbent Dose}

Aliquots of $25 \mathrm{~mL}$ solution containing $20 \mathrm{ppm}$ iron are transferred to a group of $100 \mathrm{~mL}$ conical flasks. Adjust the $\mathrm{pH}$ of each flask to the optimum value. Varying amounts of the crude green clover leaves powder in the range $0.05-0.35 \mathrm{~g}$ are added to each flask, respectively. The mixtures were stirred for $1 \mathrm{~h}$. The residual iron content in the supernatant soln. separated by centrifugation is determined spectrophotometrically.

\section{iii. Contact Time}

A group of $100 \mathrm{~mL}$ conical flasks, each of which is charged with $0.2 \mathrm{~g}$ of the crude green clover leaves powder and aliquots of $25 \mathrm{~mL}$ solution containing $20 \mathrm{ppm}$ of iron at the optimum $\mathrm{pH}$ and the shaking time is changed for different intervals of time (10-80 min.) for each flask in its role, respectively.

\section{iv. Metal Ion Concentration range}

Applying the optimum conditions of the weight of green clover leaves powder, $\mathrm{pH}$ and stirring time in a group of flasks. Aliquots of $25 \mathrm{ml}$ solution containing varying concentrations of iron in the range 10-100 ppm are added to the flasks, respectively. The same procedure is applied and the residual iron content is determined from which the uptake percent is calculated.

\section{v. Optimum Sample Volume}

Different volumes of iron samples in the range from 10-100 $\mathrm{mL}$ were used.

\section{Results and Discussion}

Cellulosic materials and their derivatives have shown quite good metal ion adsorptive capacity. Among all the heavy metal removal techniques reported so far, adsorption technique using cellulose-based agricultural waste products appears to be most attractive since it is an effective and relatively simple method for removal of heavy metal ions. However, the leaves and pseudostem are usually discarded as waste products of the food and herbalism industries.

The use of plant's leaves is reported in literature for the removal of various heavy metals from wastewater e.g., adsorption of thallium(I) ions using eucalyptus leaves powder [10], the adsorption of lead by maize leaf [36], Cu(II) by teak leaves powder [37], $\mathrm{Pb}$ by Lalang (Imperata cylindrica) leaf powder [39], Zn(II) by leaves of saltbush(Atriplex canescens) $[42,43]$, by cypress and cinchona leaves [49], $\operatorname{Cr}(\mathrm{VI})$ by black tea leaves [50] and biosorption of $\mathrm{Cu}(\mathrm{II}), \mathrm{Pb}(\mathrm{II})$, and and $\mathrm{Cu}(\mathrm{II})$ ions in aqueous solutions using Mangifera indica (Mango) leaf powder [51].

Hence, the thinking of trying green clover leaves fine powder as a low cost adsorbent for the treatment of a real local problem viz., the flourishing existence of iron (and manganese) in the ground water of some wells at El-Wasta, a town which lies 35 $\mathrm{Km}$ to the north of Beni-Suef Governorate.

Different factors that affect the adsorption process have been extensively studied to improve the uptake $\%$ of iron from the aqueous solutions.

\section{Optimum pH}

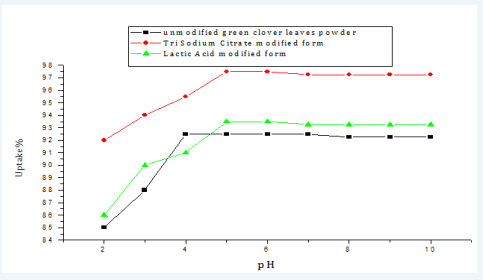

Figure 1: Effect of $\mathrm{pH}$ on the adsorption of iron on the crude and modified green clover leaves powder.

The $\mathrm{pH}$ of the aqueous solution plays the most important role in the adsorption process. It not only influences the speciation of metal ions but also the charges on the sorption sites. The results indicated low sorption efficiency at low $\mathrm{pH}$ values $(\mathrm{pH}=2-3)$. This was attributed to the high concentration and high mobility of $\mathrm{H}^{+}$, which are preferentially adsorbed rather than metal ions $[52,53]$. The removal efficiency of the sorbent is increased by increasing the $\mathrm{pH}$ value until reaches its maximum uptake at the range 4-7 by the unmodified green clover. The sodium citrate and lactic acid modified green clover powders showed maximum uptake at pH range 5-6 (Figure 1). Heavy metal biosorption onto specific and non specific biosorbents is $\mathrm{pH}$ dependent; other researchers [54] found that an increase in adsorption is a result of increasing the $\mathrm{pH}$ of the solution (Figure 1).

\section{Stirring Time}

The amount of removed metal ions by adsorption depends on the time after which equilibrium is reached, this is expressed as the equilibrium time. The results indicate that removal was slow 
in the first 35 min then the uptake \% was gradually increased till equilibrium at $50 \mathrm{~min}$ for the unmodified powder. While the powder modified with tri sodium citrate shows equilibrium after $40 \mathrm{~min}$ and the lactic acid form reached equilibrium after $50 \mathrm{~min}$. The rate of biosorption seems to occur in two steps, the first one is very rapid surface biosorption, while the second is slow intracellular diffusion (Figure 2).

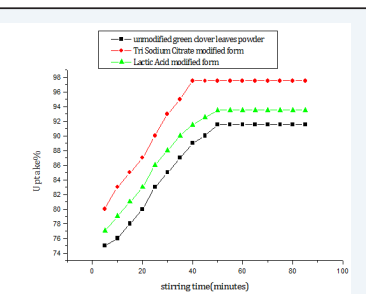

Figure 2: Effect of stirring time on the adsorption of iron on the crude and modified green clover leaves powders.

\section{Sorbent Dose}

The biosorbent dose is considered the most important parameter affecting the removal efficiency. For the unmodified powder, a dose of $0.35 \mathrm{~g}$ sorbent has achieved an uptake of $91 \%$ of iron at optimum $\mathrm{pH}$ conditions. While for the tri sodium citrate modified form, a dose of $0.25 \mathrm{~g}$ achieved an uptake $\%$ of iron of $97.5 \%$. Correspondingly, $0.25 \mathrm{~g}$ of the lactic acid modified one achieved iron removal of $93.5 \%$ (Figure 3)

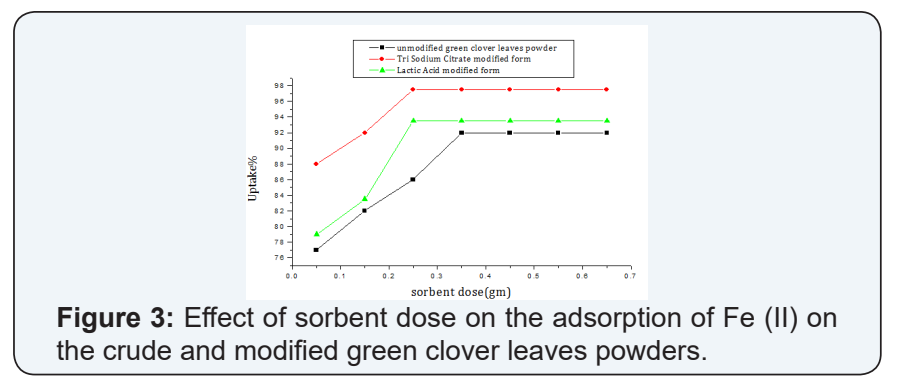

\section{Initial Metal ion Concentration}

At lower concentrations the adsorption sites utilized the available metal ion more rapidly when compared to higher concentrations where the metal ions need to diffuse to the sorbent surface by intra particle diffusion. The maximum metal uptake was $92 \%$ in the case of the unmodified green clover, $94 \%$ for lactic acid modified powder and $97 \%$ in the case of tri sodium citrate modified form at metal ion concentration of 10 ppm (Figure 4).

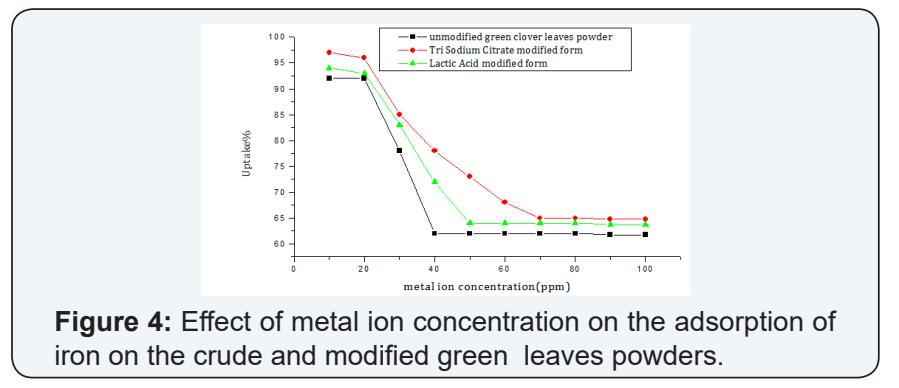

\section{Sample volume}

At optimum conditions the volume of $25 \mathrm{~mL}$ achieved the best adsorption percentage with all tested green clover leaves powders. It is clear from the figure that iron removal decreases with the increase of volume (Figure 5)

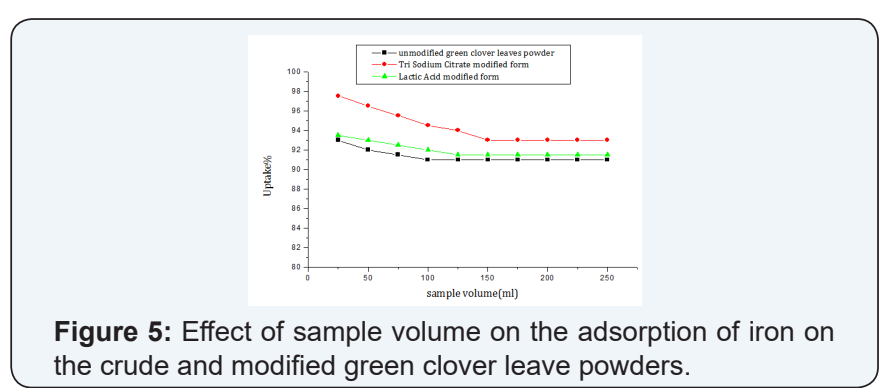

The morphologies of the prepared adsorbents and composites

Structures and morphologies of the crude green clover powder, its loaded composites with lactic acid and trisodium citrate ones are studied by X-ray diffraction (XRD) and scanning electron microscopy (SEM) (Figure 6). Anchor scan parameters, graphics and the peak list for every xrd scan. These scans assure the successful loading (modifying) of the crude green clover leaves powder with the two modifiers viz., lactic acid and trisodium citrate. Modification succeeded in increasing the removal percentage, but hasn't had any improvement effect on selectivity.

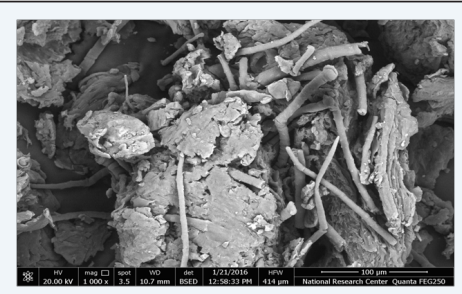

Figure 6: Structures and morphologies of the crude green clover powder.

XRD scans assures the successful loading of the crude powder with the two modifiers used.

\section{Selectivity of the adsorbent}

Adsorption studies applying the three adsorbents, under study, proved that they are nonselective towards heavy metals that may be present in wastewaters as pollutants. The spiking of the iron authentic samples with different concentrations of other metal ions e.g., $\mathrm{Fe}(\mathrm{III}), \mathrm{Mn}(\mathrm{II}), \mathrm{Ni}(\mathrm{II})$ and $\mathrm{Cu}$ (II) resulted in additive concentrations of the collection of metal ions present in a solution without any discrimination among them.

However, the non selectivity of such types of adsorbents is frequent in the literature, their tolerance is attributed to being low cost and available. Current work in our laboratory is devoted for the development and applications of selective and low cost adsorbent. 


\section{International Journal of Environmental Sciences \& Natural Resources}

\section{Desorption studies}

The adsorbed iron ions on the adsorbent surface are treated with $25 \mathrm{~mL} 0.1 \mathrm{M} \mathrm{HCl}$ and stirred for $1 \mathrm{~h}$. The amount of iron ions remained in the solution after filtration or centrifugation was measured using the recommended spectrophotometric method and the percentage desorption $\left(\mathrm{R}_{\mathrm{b}}\right)$ was calculated according to the relation:

$$
\mathrm{R}_{\mathrm{b}}=\frac{\mathrm{C}_{\mathrm{t}}}{\mathrm{C}_{\mathrm{a}}} 100
$$

where $C_{t}$ is the experimental concentration in the solution at time $\mathrm{t}(\mathrm{ppm}), \mathrm{C}_{\mathrm{a}}$ is the adsorbed concentration of sorbate onto the adsorbent.

i. Effect of $\mathbf{p H}$ on desorption of iron: In strong acidic media at $\mathrm{pH}$ range(1.4-2.2)the three forms of the green clover leaves powder showed high desorption percentages, on increasing the $\mathrm{pH}$ values desorption percentage decreases (Figure 7).

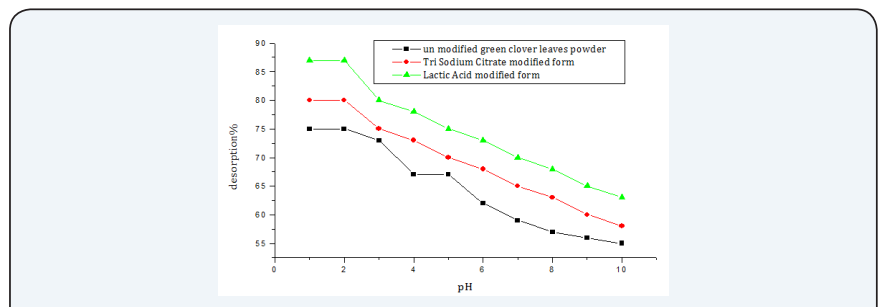

Figure 7: Effect of $\mathrm{pH}$ on desorption of iron on the crude and modified green clover leaves powders.

ii. Stirring Time: The desorption percentages \% were gradually increased till equilibrium at $35 \mathrm{~min}$ for the unmodified and lactic acid modified powders, while the powder modified with tri sodium citrate shows equilibrium after $40 \mathrm{~min}$. A value of $89 \%$ has been recorded for the unmodified green clover powder, $93 \%$ for the trisodium citrate modified form and $91 \%$ for lactic acid one (Figure 8).

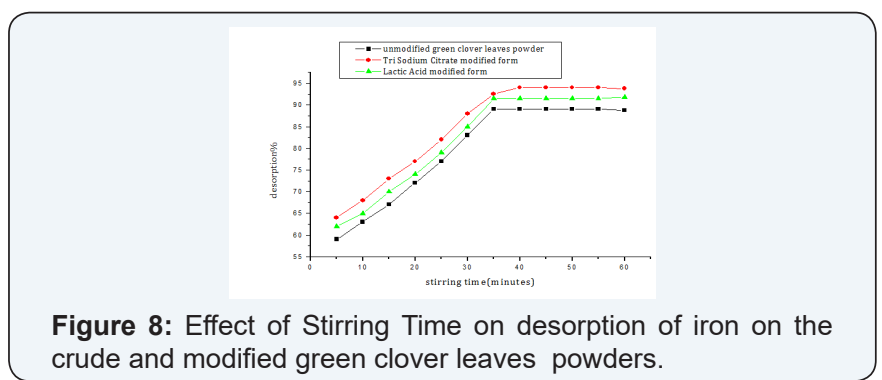

Table 1: Summary of the optimum conditions for the adsorption of Iron on the green clover leaves powder.

\begin{tabular}{|c|c|c|c|}
\hline Parameter & $\begin{array}{c}\text { Unmodified } \\
\text { Green Clover } \\
\text { Leaves } \\
\text { powder }\end{array}$ & $\begin{array}{c}\text { Tri sodium } \\
\text { citrate } \\
\text { modified } \\
\text { green clover } \\
\text { powder }\end{array}$ & $\begin{array}{c}\text { Lactic acid } \\
\text { modified } \\
\text { green clover } \\
\text { powder }\end{array}$ \\
\hline $\mathrm{pH}$ & $4-7$ & $5-6$ & $5-6$ \\
\hline $\begin{array}{c}\text { Optimum } \\
\text { shaking time }\end{array}$ & $50 \mathrm{~min}$ & $40 \mathrm{~min}$ & $50 \mathrm{~min}$ \\
\hline
\end{tabular}

\begin{tabular}{|c|c|c|c|}
\hline $\begin{array}{c}\text { Metal } \\
\text { concentration } \\
20 \mathrm{ppm} \\
\text { (uptake\%) }\end{array}$ & $92 \%$ & $97.5 \%$ & $94 \%$ \\
\hline Sorbent dose & $0.35 \mathrm{~g}$ & $0.25 \mathrm{~g}$ & $0.25 \mathrm{~g}$ \\
\hline Sample volume & $25 \mathrm{~mL}$ & $25 \mathrm{~mL}$ & $25 \mathrm{~mL}$ \\
\hline
\end{tabular}

iii. Real samples: Water samples collected from tap water, Bahr Youssef water, ground water and Ibrahemia water, samples were subjected to the adsorption procedure as illustrated previously and the residual iron is analyzed by two methods of finish viz., colorimetry and AAS (Table 2).

Table 2: Determination of iron in real water samples.

\begin{tabular}{|c|c|c|}
\hline Colorimetry & AAS & Water samples \\
\hline $0.615 \mathrm{ppm}$ & $0.448 \mathrm{ppm}$ & Bahr yousef \\
\hline $1.426 \mathrm{ppm}$ & $1.124 \mathrm{ppm}$ & Ground water \\
\hline $0.978 \mathrm{ppm}$ & $0.777 \mathrm{ppm}$ & Ibrahimia water \\
\hline $0.355 \mathrm{ppm}$ & $0.291 \mathrm{ppm}$ & Drinking water \\
\hline
\end{tabular}

\section{Conclusion}

Green clover leaves powders proved to be potential biosorbents for the removal of iron from aqueous solutions being available low cost material. Results of desorption study also confirmed that there is a possibility to regenerate and reuse the biosorbent again.

\section{Acknowledgement}

The authors are thankful to the Publishers of the International Journal of Environmental Sciences \& Natural Resources IJESNR for the publication gift provided.

\section{References}

1. Garba ZN, Afidah AR (2015) Optimization of activated carbon preparation conditions from Prosopisafricana seed hulls for the removal of 2,4,6-Trichlorophenol from aqueous solution. Desalination Water Treat 56: 2879-2889.

2. Garba ZN, Afidah AR, Bello BZ (2015) Optimization of preparation conditions for activated carbon from Brachystegiaeurycomaseed hulls: a new precursor using central composite design. J Environ Chem Eng 3(4): 2892-2899.

3. Garba ZN, Shikin FBS, Afidah AR (2015) Valuation of activated carbon from waste tea for the removal of a basic dye from aqueous solution. J Chem Eng Chem Res 2(5): 623-633.

4. Garba ZN, Ubam S, Babando AA, Galadima A (2015) Quantitative assessment of heavy metals from selected tea brands marketed in Zaria, Nigeria. J Phys Sci 26(1): 43-51.

5. Barakat MA (2011) New trends in removing heavy metals from industrial wastewater. Arabian Journal of Chemistry 4: 361-377.

6. Ozdes D, Gundogdu A, Kemer B, Duran C, Senturk HB et al. (2009) Removal of $\mathrm{Pb}(\mathrm{II})$ ions from aqueous solution by a waste mud from copper mine industry: equilibrium, kinetic and thermodynamic study. J Hazard Mater 166(2-3): 1480-1487.

7. Tuzen M, Sari A, Mendil D, Soylak M (2009) Biosorptive removal of mercury(II) from aqueous solution using lichen (Xanthoparmeliaconspersa) biomass: kinetic and equilibriumstudies. J Hazard Mater 169(1-3): 263-270. 
8. Alslaibi TM, Abustan I, Ahmad MA, Abu Foul A (2013) Cadmium removal from aqueous solution using microwaved olive stone activated carbon. J Environ Chem Eng 1(3): 589-599.

9. Verlicchi P, Galletti A, Petrovic M, Barcelo D (2010) Hospital effluents as a source of emerging pollutants: an overview of micropollutants and sustainable treatment options. J Hydrol 389(3-4): 416-428.

10. Khavidaki HD, Aghaie H (2013) Adsorption of thallium(I) ions using eucalyptus leaves powder. Clean 41(7): 673-679.

11. Kobya M, Demirbas E, Senturk E, Ince M (2005) Adsorption of heavy metal ions from aqueous solutions by activated carbon prepared from apricot stone. Bioresour Technol 96(13): 1518-1521.

12. Krishnan KA, Sreejalekshmi KG, Baiju RS (2011) Nickel (II) adsorption onto biomass based activated carbon obtained from sugarcane bagasse pith. Bioresour Technol 102(22): 10239-10247.

13. Kula I, Ugurlu M, Karaoglu H, Celik A (2008) Adsorption of Cd (II) ions from aqueous solutions using activated carbon prepared from olive stone by $\mathrm{ZnCl}_{2}$ activation. Bioresour Technol 99(3): 492-501.

14. Garba ZN, Afidah AR (2014) Process optimization of $\mathrm{K}_{2} \mathrm{C}_{2} \mathrm{O}_{4}$-activated carbon from Prosopis africana seed hulls using response surface methodology. J Anal Appl Pyrolysis 107: 306-312.

15. Garba ZN, Afidah AR, Hamza SA (2014) Potential of Borassus aethiopum shells as precursor for activated carbon preparation by physico-chemical activation; optimization, equilibrium and kinetic studies. J Environ Chem Eng 2(3): 1423-1433.

16. Mohan D, Singh KP, Sing VK (2008) Waste water treatment using low cost activated carbons derived from agricultural byproducts -a case study. J Hazard Mater 152(3): 1045-1053.

17. Mondal S, Sinha K, AikatK, Halder G (2015) Adsorption thermodynamics and kinetics of ranitidine hydrochloride onto superheated steam activated carbon derived from mung bean husk. J Environ Chem Eng 3: 187-195.

18. Beenakumari KS (2009) Removal of iron from water using modified coconut shell charcoal as adsorbent. Current World Environment 4(2): 321-326.

19. Soylak M, Erdogan ND (2006) Copper (II)-rubeanic acid coprecipitation system for separation -preconcentration of trace metal ions in environmental samples for their flame atomic absorption spectrometric determinations. J Hazard Mater 137(2): 1035-1041.

20. Ryoma BE, Kawasaki N, Ogata F, Nakamura T, Aochi K et al. (2006) Removal of lead and iron ions by vegetable bio mass in drinking water Journal of oleo science 55(8): 423-427.

21. Munter R, Ojaste H, Sutt J (2005) Complexed iron removal from ground water. J Environm Eng 131(7): 1014-1020.

22. Regina de Moreira FPM, Madeira VS, Jose E, Humeres HJ (2010) Removal of iron from water using adsorbent carbon. Sepn Sc Technol 39(2): 271-285

23. Aziz HA, Yusoff MS, Adlan MN, Adnan NH, Alias S (2003) Physicochemical removal of iron from semi aerobic landfill leachable by limestone filter. Waste Manag 24(4): 353-358.

24. Mohan D, Singh KP (2002) Single and multi-component adsorption of cadmium and zinc using activated carbon derived from bagasse - an agricultural waste. Water Res 36(9): 2304-2318.

25. Khan NA, Ali SI, Ayub S (2001) Effect of pH on the removal of chromium (Cr) (VI) by sugar cane baggase. Sci Technol 6: 13-19.

26. Ayub S, Ali SI, Khan NA (2002) Adsorption studies on the lowcost adsorbent for the removal of $\mathrm{Cr}$ (VI) from electroplating wastewater Environ Pollut Control J 5(6): 10-20.

27. Ajmal M, Rao RA, Anwar S, Ahmad J, Ahmad R (2003) Adsorption studies on rice husk: removal and recovery of Cd (II) from wastewater Bioresour Technol 86(2): 147-149.
28. Khan NA, Shaaban MG, Jamil Z (2003) Chromium removal from wastewater through adsorption process, in: Proc. UM Research Seminar organized by Institute of Research Management and Consultancy (IPPP) University of Malaya, Kuala Lumpur.

29. Kadirvelu K, Kavipriya M, Karthika C, Radhika M, Vennilamani N et al. (2003) Utilization of various agricultural wastes for activated carbon preparation and application for the removal of dyes and metal ions from aqueous solution. Bioresour Technol 87(1): 129-132.

30. Selvi K, Pattabhi S, Kadirvelu K (2001) Removal of Cr (VI) from aqueous solution by adsorption onto activated carbon. Bioresour Technol 80: 87-89.

31. Khan NA, Shaaban MG , Hassan MHA (2003) Removal of heavy metal using an inexpensive adsorbent, in: Proc. UM Research Seminar organized by Institute of Research Management and Consultancy (IPPP) University of Malaya, Kuala Lumpur.

32. Ayub S, Ali SI, Khan NA (2001) Efficiency evaluation of neem (Azadirachtaindica) bark in treatment of industrial wastewater. Environ Pollut Control J 4 (4): 34-38.

33. Saeed A, Iqbal M (2003) Bioremoval of cadmium from aqueous solution by black gram husk (Cicerarientinum). Water Res 37(14): 3472-3480.

34. Orhan Y, Buyukgungor H (1993) The removal of heavy metals by using agricultural wastes. Water Sci Technol 28(2): 247-255.

35. Saeed A, Iqbal M, Akhtar MW (2005) Removal and recovery of heavy metals from aqueous solution using papaya wood as a new biosorbent. Sep. Purif Technol 45: 25-31.

36. Babarinde NAA, Oyebamiji BJ, Adebowale Sanni R (2006) Biosorption of lead ions from aqueous solution by maize leaf. Int J Phys Sci 1(1): $23-26$.

37. King P, Srivinas P, Prasanna Kumar Y, Prasad VSRK (2006) Sorption of copper (II) ion from aqueous solution by Tectona grandis l.f. (teak leaves powder). J Hazard Mater 136(3): 560-566.

38. Karunasagar D, Krishna MV, Rao SV, Arunachalam J (2005) Removal and preconcentration of inorganic and methyl mercury from aqueous media using a sorbent prepared from the plant Coriandrum sativum. J Hazard Mater 118(1-3): 133-139.

39. Hanafiah MAK, Ngah WSW, Zakaria H, Ibrahim SC (2007) Batch study of liquid-phase adsorption of lead ions using Lalang (Imperatacylindrica) leaf powder. J Biol Sci 7(2): 222-230.

40. Johnson PD, Watson MA, Brown J, Jefcoat IA (2002) Peanut hull pellets as a single use sorbent for the capture of $\mathrm{Cu}$ (II) from wastewater Waste Manage 22(5): 471-480.

41. Quek SY, Wase DAJ, Forster CF (1998) The use of sago waste for the sorption of lead and copper. Water SA 24(3): 251-256

42. Sawalha MF, Peralta-Videa JR, Romero-Gonzalez J, Duarte-Gardea M, Gardea Torresdey JL (2007) Thermodynamic and isotherm studies of the biosorption of $\mathrm{Cu}$ (II), Pb (II), and $\mathrm{Zn}$ (II) by leaves of saltbush(Atriplexcanescens). J Chem Thermodyn 39(3): 488-492.

43. Sawalha MF, Peralta-Videa JR, Romero-Gonzalez J, Gardea-Torresdey JL (2007) Biosorption of Cd (II), Cr (III), and Cr(VI) by saltbush (Atriplexcanescens) biomass: thermodynamic and isotherm studies. Colloid Interface Sci 300(1): 100-104.

44. Ho YS, Wang CC (2004) Pseudo-isotherms for the sorption of cadmium ion onto tree fern. Process Biochem 39(6): 759-763.

45. Ho YS, Chiu WT, Hsu CS, Huang CT (2004) Sorption of lead ions from aqueous solution using tree fern as a sorbent. Hydrometallurgy 73: 5561.

46. Villaescusa I, Fiol N, Martinez N, Miralles N, Poch J, et al. (2004) Removal of copper and nickel ions from aqueous solutions by grape stalks wastes. Water Research 38(4): 992-1002.

47. Cao J, Wu Y, Jin Y, Yilihan P, Huang W (2014) Response surface methodology approach for optimization of the removal of 
chromium(VI) by NH2-MCM-41. J Taiwan Inst Chem Eng 45(3): 860-8.

48. Mohammadi M, Ghaemi A, Torab-Mostaedi M, Asadollahzadeh M, Hemmati A (2015) Adsorption of cadmium (II) and nickel (II) on dolomite powder. Desalination Water Treat 53(1): 149-157.

49. Ajmal M, Rao RA, Ahmad R, Ahmad J (2000) Adsorption studies on Citrus reticulata (fruit peel of orange): Removal and recovery of Ni (II) from electroplating wastewater. J Hazard Mater 79(1-2): 117-131.

50. Annadurai G, Juang RS, Lee DJ (2002) Use of cellulose-based wastes for adsorption of dyes from aqueous solutions. J Hazard Mater 92(3): 263-274

51. Zhonghua Hu, Lin Lei, Yijiu Li, Yaming Ni (2003) Chromium adsorption on high-performance activated carbon from aqueous solution. Sep Purif Technol 31(1): 13-18.
52. Al Subu MM (2002) The Interaction effects of cypress (Cupressus sempervirens), Cinchona (Eucalyptus longifolia) and pine (Pinus halepensis) leaves on their efficiencies for lead removal from aqueous solutions. Adv Environ Res 6(4): 569-576.

53. Kumita M, Hossain MA, Michigami Y, Mori S (2005) Optimization of parameters for $\mathrm{Cr}$ (VI) adsorption on used black tea leaves. Adsorption 11(5): 561-568.

54. Sethu V, Goey KS, Iffah FR, Khoo CM, Andresen JM (2010) Adsorption characteristics of $\mathrm{Cu}(\mathrm{II})$ ions in aqueous solutions using Mangifera indica (Mango) leaf biosorbents. J Environm Res Develop 5(2): 262278.
Your next submission with Juniper Publishers will reach you the below assets

- Quality Editorial service

- Swift Peer Review

- Reprints availability

- E-prints Service

- Manuscript Podcast for convenient understanding

- Global attainment for your research

- Manuscript accessibility in different formats

( Pdf, E-pub, Full Text, Audio)

- Unceasing customer service

Track the below URL for one-step submission https://juniperpublishers.com/online-submission.php 